\title{
3 次元空間における注意の分布
}

\author{
○瀬谷安弘・篠田博之 (非会貝) \\ (立命館大学情報理工学部知能情報学科) \\ キーワード：注意, 両眼視差, 有効視野課題
}

\begin{abstract}
Spatial distribution of attention in three-dimensional space
Yasuhiro SEYA and Hiroyuki SHINODA

(Department of Human and Computer Intelligence, College of Information Science and Engineering, Ritsumeikan University)

Key Words: Attention, Binocular disparity, Useful field of view task
\end{abstract}

\section{目 的}

自動車の運転やスポーツ場面など様々な日常生活場面にお いて，私たちは視野内全ての情報を知覚・認知しているので はなく，特定の範囲の情報を選択的に知覚・認知している。 このような情報の選択機能は注意と呼ばれ，これまで多くの 研究において，注意の分布や形状といった注意の空間特性に 関する検討がなされてきた。しかしこの種の研究の多くは 2 次元空閒上での注意の分布を検討しており，3次元空問にお ける注意の分布についての检討は必ずしも十分ではない.

3 次元空間に扮ける注意の分布に関与る研究として, Previc \& Blume (1993) が挙げられる。彼らの研究では, 両眼視差 を操作した結合探索課題を用い，奥行方向も含めた刺激の位 惪が探索成績に及ぼす影響を検討した。結果は，ターゲット 刺激が注視刺激より前後の空間に提示された場合に，注視刺 激と同じ平面上に提示された場合よりも，反応時間が遅くな ることを示し，注意が 3 次元的に分布している可能性を示唆 する。但し, Previc \& Blume（1993）は探索課題を用いている ことから, 彼らの結果は, 注意の分布ではなく, 注意の移動 特性を反映している可能性がある。

本研究では注意の空間的分布の検討に用いられる有効視野 課題を用い，その刺激の両眼視差を操作することで, 注意の 分布における 3 次元空間特性にひいて倹䚯した。

\section{方 法}

被験者：実験 1 と 2 では 8 名, 実験 3 では 10 名であった， 装置と刺激：刺激はプロジェクターでスクリーント（61.9 × $56.1^{\circ}$ ) に提示さ机た。刺激は注視刺激と文字刺激（中心夕一 ゲット), 円枠, 光点 (周辺ターゲット), マスク刺激で構成 され，灰色の背景上に白色で提示された，注視刺激はデジ夕 ル数字の 8 であり，スクリーンの中央に提示された。 大きさ

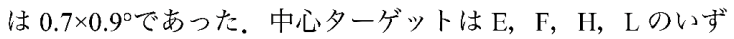
れかであり，注視刺激と同じ位惪に提示された。 大きさは $0.7 \times 0.9^{\circ}$ であった。 円枠は画面中心から斜女 4 方向に 4,12 , $20^{\circ}$ の位置に配置された。周辺夕ーゲットは円枠のいずれか 1 つの中央に提示された。 マスク刺激は格子模様を付した円刺 激であり，12 個の円枠及び中心ターゲットと同じ位置に提示 された。

実験 1 ・2では, 両眼視差を操作することで円枠や周辺ター ゲット，マスク刺激の奥行が，近距離（注視刺激より前方 20 $\mathrm{cm}$ ), 同距離, 遠距離条件（後方 $20 \mathrm{~cm}$ ）のいず扎小に設定さ れた。実験 1 では，知覚的な奥行に合わせて刺激の大きさが 操作され, 円枓とマスク刺激け大きさは, 近距離, 同距離, 哀距離条件でそれぞれ，1.6，1.3，1.1，诗辺夕ーゲットの大 きさは $1.1,0.9,0.80$ であった。実験 2 では，奥行条件に関わ らず，刺激の大きさは一定であり，円枠とマスク刺激の大き

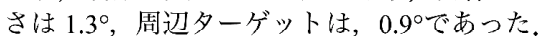

実験 3 では, 中心刺激と中心ターゲット, そのマスク刺激 の両眼視差を操作した以外は, 刺激は実験 2 と同じであった。 手続き：被験者は専用のゴーグルを装着し，100cmの距離か ら刺激を観察した。各試行の始めに，Readyの文字が提示さ れ，被験者がスペースを押すと，注視刺激と円枠が 1 秒間提 示された。 その後, 中心及び周辺ターゲットが $100 \mathrm{~ms}$ 間提示 され, 続いてマスク刺激が 1 秒間提示された。マスク刺激が 消えると. 中心夕ーゲットの同定を求める画面が提示され. その後, 周切ターゲットの定位を求める画面が提示された。 被験者の課題は，中心ターゲットを正確に同定すると共に， 周辺ターダットを定位することであった，実験では，各条件 (奥行 3 条件×周辺夕ーゲットの位置 12 条件) において, 20 試行ずつ行い，中心及び周辺課題ひ正答率を算出した.

\section{結 果 と 考 察}

3 実験いずれにおいても, 中心課題の正答率は 0.95 以上で あり, 奥行条件による有意な変化はなかった

実験 $1 \cdot 2$ の周辺課題成績の結果を図 $1 \mathrm{~A}$ に示す。実験 1 の 結果は, 偏心度や奥行, それらの交互作用によって正答率が 変化することを示した $(p s<0.05)$. 但し, 䒠験 2 の周辺課題の 結果は, 偏心度の効果は有意であったが $(p<0.05)$, 奥行条件 や交互作用は有意ではなかった。この結果は, 実験 1 の結果 が奥行の効果ではなく, 刺激の大きさの効果を反咉している 可能性を示唆する。すなわち, 実験 1 ・ 2 の結果は, 注意が奥 行方向には分布していない可能性を示唆与る。

図 $1 \mathrm{~B}$ に，実験 30 周辺課題成績を示す。周辺ターゲット の奥行きは常に同じであるにも関わらず，結果は周辺ターゲ ットが中心ターゲットに詨して異なる奥行にある場合に，同 じ場合よりも正答率が低いことを示した。この結果は, 注意 が奥行方向にも分布している可能性を示唆する. 実験 $1 \cdot 2$ と の結果の違いについては, 中心及び周辺視野での視差に対す る感度の違いによって生じた可能性がある。

\section{引用文献}

Previc, F., \& Blume, J. (1993). Vision Research, 18, 2697- 2704.

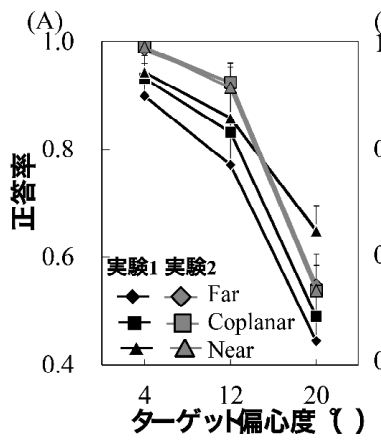

(B)

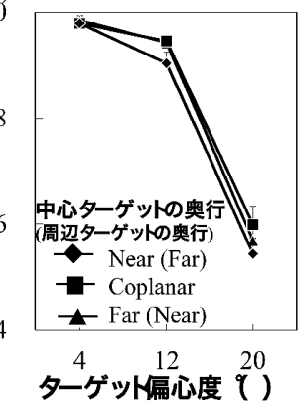

汹 1 . 実験 1 - 2 と実験 3 の倜辺課題成績 (縦棒は SE を示す). 